\title{
ELECTRODEPOSITION OF CADMIUM ON N-TYPE SILICON SINGLE CRYSTALS OF DIFFERENT SURFACE ORIENTATIONS
}

BOUBIÉ GUEL

(Received 29, February 2007; Revision Accepted 25, February 2008)

\section{ABSTRACT}

The mechanisms related to the initial stages of the nucleation and growth mechanism of cadmium on (100) and (111) ntype silicon have been studied as a function of different potential steps. Within appropriate potential ranges the initial deposition kinetics corresponds to a model including progressive nucleation and diffusion controlled cluster growth. Nucleation rate and the number of atoms in the critical nucleus are determined from the analysis of current transients at different overpotentials. Values of $\mathrm{N}_{\text {crit }}$ are $16 \pm 1(-16 \mathrm{mV} \geq \eta \geq-19 \mathrm{mV})$ and $7 \pm 1(-14 \mathrm{mV} \geq \eta \geq-18 \mathrm{mV})$ for $\mathrm{n}-\mathrm{Si}(100)$ and $\mathrm{n}-\mathrm{Si}(111)$ respectively.

KEYWORDS: Electrodeposition; n-Si(111); n-Si(100); Nucleation and growth mechanism.

\section{INTRODUCTION}

The process of electrolytic deposition of metals on metal and semiconductor substrates is gaining considerable scientific interest because it is a relatively low energy process compared with other methods such as conventional UHV deposition. From a technological standpoint, metal deposition in form of thin films on semiconductor surface is important in the fabrication of integrated circuits (Brillsoin, 1982) and solar energy conversion (Allongue, 1992).

In recent years, various metals have been successfully electrodeposited on metal and semiconductor substrates. A comprehensive review of metal electrodeposition can be found in (Budesvski, et al.). The interest in thin films of cadmium is increasing considerably due to its use in the electrodeposition of $\mathrm{CdX}(\mathrm{X}=\mathrm{S}$, Se, Te, O) compound thin films or nanostructures (Hodes, et al., 1992; Hodes, 1993; Golan, et al., 1994; Gómez, et al., 2004; Gómez, et al., 2005; Djenizian, et al., 2001; Ortega, et al., 2000). Since these thin films or nanostructures are grown from plating bath containing $\mathrm{Cd}^{2+}$ ions, it is of great interest to understand the fundamentals of cadmium electrodeposition. Although many works have been carried out on the cadmium electrodeposition on various substrates such as $\mathrm{Bi}, \mathrm{Sn}$ and $\mathrm{Pb}$ (references cited in Maupai, et al., 2003), Ag (Bort, et al., 1983), Au (Maupai, et al., 2003; Vidu, et al., 2000), Cu (Hümann, et al., 2003), or GaAs (Khader, et al., 1999), only a limited number of fundamental studies of $\mathrm{Cd}$ electrodeposition have been carried out on silicon single crystals. In previous work (Krumm, et al., 2000) we examined $\mathrm{Cd}$ electrodeposition, from a solution containing $5 \times 10^{-3} \mathrm{M} \mathrm{Cd}^{2+}$ ions, on $\mathrm{n}-\mathrm{Si}(111)\left(1-5 \Omega \mathrm{cm}\right.$ resistivity and $0^{\circ}$ misorientation). It was shown that within appropriate potential ranges the initial deposition kinetics corresponded to a model including progressive nucleation on active sites and diffusion controlled cluster growth. Nucleation rate and the number of atoms $\mathrm{N}_{\text {crit }}$ in the critical nucleus were determined from the analysis of current transients at different overpotentials. A value of 6 was derived for $N_{\text {crit }}$ with an accuracy of \pm 1 in the overpotential range $-15 \geq \eta \geq-21 \mathrm{mV}$ (Krumm, et al., 2000).

Generally, the technique used for deposition is as follows: the working electrode is prepolarized with respect to the reference in solution at a selected underpotential $\Delta \mathrm{E}_{\mathrm{i}}$, where no current flows. At $t=0$, the potential step raises the Fermi level to a potential corresponding to an overpotential $\eta=$ $\left(E-E \mathrm{Me}^{Z+}, \mathrm{Me}\right)<0$. The main electrocrystallization parameters besides those relative to the substrate are $\Delta E_{i}, \eta$, the time of deposition and the solution composition $\mathrm{pH}$, concentration, etc.). The purpose of this paper is a comparative study of the initial stages of nucleation and growth of electrodeposited $\mathrm{Cd}$ on n-type silicon single crystals of different surface orientations. This work confirms the strong orientation dependence of the electrochemical process and is therefore of fundamental interest in electrochemical phase formation, phase transition and dissolution processes which play an important role in the preparative aspect of electrochemical nanotechnology.

\section{METHODS}

The investigations were carried out in the systems ${ }^{\circ}$ : $\mathrm{n}-\mathrm{Si}(h k l) / 5 \times 10^{-3} \mathrm{M} \mathrm{CdSO}_{4}+0.5 \mathrm{M} \mathrm{Na}_{2} \mathrm{SO}_{4}+5 \times 10^{-3} \mathrm{M}$ $\mathrm{H}_{2} \mathrm{SO}_{4} ; \mathrm{pH}=2.5, \mathrm{~T}=298 \mathrm{~K}$, where $(h k l)=(111),(100)$.

Silicon working electrodes were made from n-type silicon wafers of different surface orientations: 1) (100) orientation, phosphorus-doped, 20-40 $\Omega \mathrm{cm}$ resistivity, MEMC Electronic Materials, Germany; 2) (111) orientation, phosphorus-doped, 40-60 $\Omega \mathrm{cm}$ resistivity, Wacker Siltronic AG, Germany. The geometrical surface area of the substrates was approximately $1 \mathrm{~cm}^{2}$.

The $\mathrm{Si}(h k l)$ substrates were subsequently cleaned in trichloroethylen, acetone and methanol and etched for $1 \mathrm{~min}$ in $2 \% \mathrm{HF}$ solution and $6 \mathrm{~min}$ in deaerated $40 \% \mathrm{NH}_{4} \mathrm{~F}$ solution. The substrates were then mounted into a Teflon holder with their polished side in contact with the electrolyte. Ohmic contact was established on the back of the Si samples with a $\mathrm{Ga} / \mathrm{In}$ eutectic.

The electrolytes were prepared from suprapure chemicals and fourfold-distilled water and deaerated by purified nitrogen prior to and during each experiment.

Conventional electrochemical measurements were performed in a three-electrode electrochemical cell with a Ptcounter electrode and a small $\mathrm{Pt}$ sphere covered with electrochemically deposited $\mathrm{Cd}$ used as the reference electrode and placed at a distance of 1-2 $\mathrm{mm}$ near the siliconworking electrode in order to ensure negligible ohmic drop in all experiments. All electrode potentials are referred to the equilibrium potential of the 3D Cd bulk phase $E_{3 D C d}$.

\section{RESULTS AND DISCUSSION}

\section{Deposition on n-Si(100), phosphorus-doped, 20-40 $\Omega \mathrm{cm}$ resistivity.}

Figure 1 shows typical cyclic voltammograms of $\mathrm{Cd}$ deposition obtained at $\mathrm{T}=298 \mathrm{~K}$ with $|\mathrm{dE} / \mathrm{dt}|=1 \mathrm{mVs}^{-1}$ in the system $\mathrm{n}-\mathrm{Si}(100) / 0.005 \mathrm{M} \mathrm{Cd}^{2+}$. In the system under investigation, no peak can be found in the UPD (underpotential 
deposition) range indicating a weak interaction (weak adhesion) of cadmium with $\mathrm{n}-\mathrm{Si}(100)$. Current loop in the OPD (overpotential deposition) range, typical of a nucleation-growth process at electrode surfaces, is observed. Actually, in such systems (semiconductor substrates) where the binding energy

of $\mathrm{Me}^{*}$ adatoms on the substrate S, i.e. ( $\Psi_{\mathrm{Me}}$ ads $\left.{ }^{-} \mathrm{S}\right)$, is lower than that of Me adatoms on the native substrate, i.e. $\left(\Psi_{\mathrm{Me}}\right.$ ads $\mathrm{Me})$, the 3D Me phase is formed in the OPD range on top of an unmodified substrate following a Volmer-Weber growth mechanism (Pötzschke, et al., 1999). Further, anodic peak corresponding to the metal stripping can be seen in the positive voltammetric scan indicating that deposition and dissolution of $\mathrm{Cd}$ are reversible in this system.
Figure 2a shows current transients for Cd deposition on $\mathrm{n}-\mathrm{Si}(100) \quad 20-40 \Omega \mathrm{cm}$ resistivity. The deposition rate increases with overpotential $\eta$. The analysis of the transients was restricted only to their initial part in order to exclude overlapping effects of growing 3D Cd clusters and/or diffusion zones. The transient current density under these conditions is

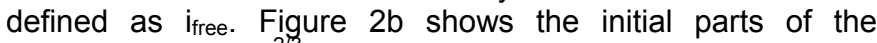
transients in a (ifree $)^{2 / 3}$ vs. $t$ plot. All the linear relationships were obtained with coefficients of determination $\mathrm{R}^{2}$ greater than 0.9025 . This indicates the goodness of fit of the data to a straight line (Billo, 1997). The obtained linear relationships correspond to a nucleation and growth model including progressive nucleation and hemispherical diffusion to the growing 3D Cd clusters, where $\mathrm{i}_{\text {free }}$ is given by (Budesvski, et al., 1996)

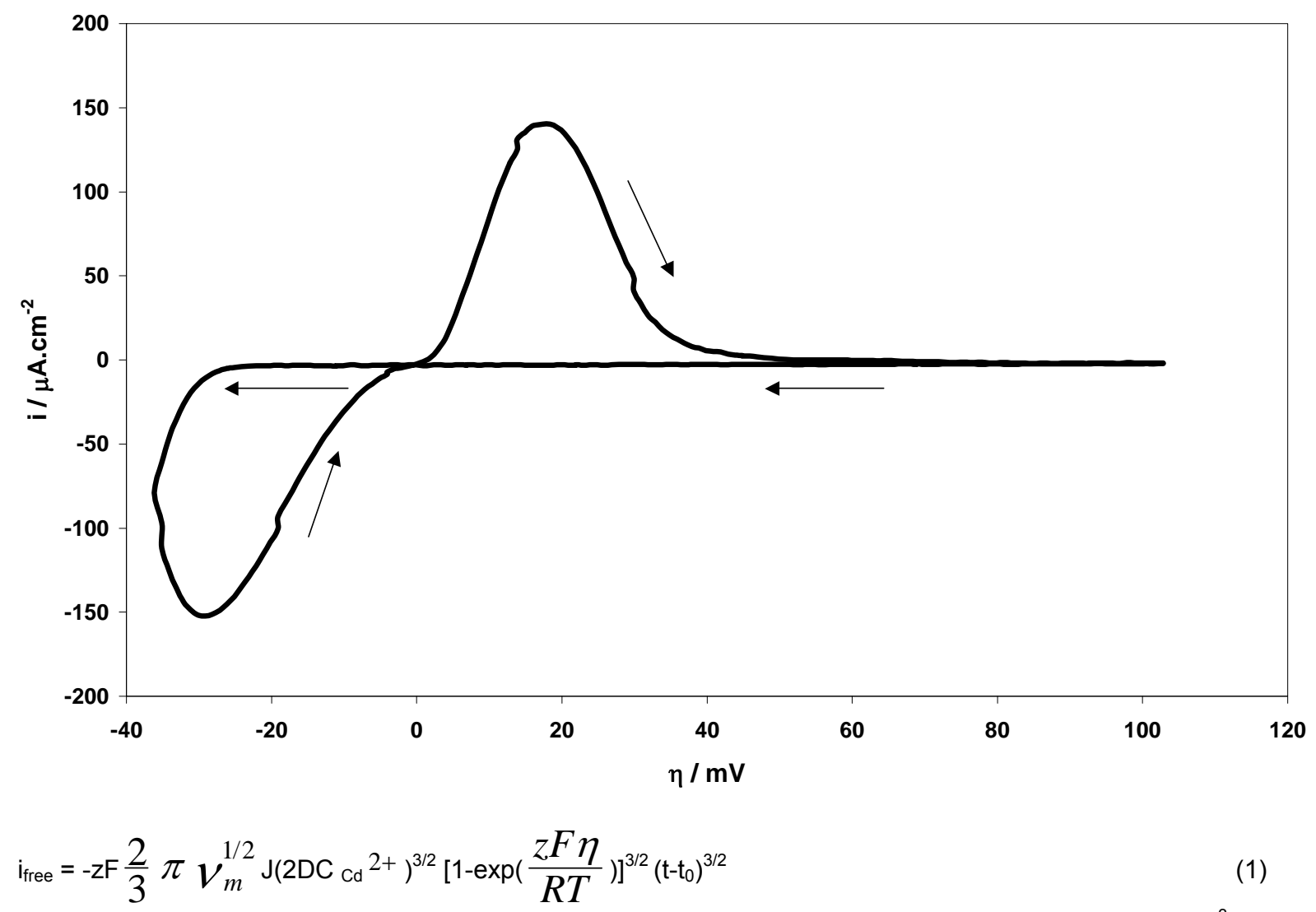

Figure 1: Cyclic voltammogram for Cd deposition and dissolution in the system n-Si(100): $20-40$ ohm.cm / $5 \times 10^{-3} \mathrm{M} \mathrm{CdSO}_{4}+0.5$ $\mathrm{M} \mathrm{Na}_{2} \mathrm{SO}_{4}+5 \times 10^{-3} \mathrm{M} \mathrm{H}_{2} \mathrm{SO}_{4} ; \mathrm{pH}=2.5, \mathrm{~T}=298 \mathrm{~K},|\mathrm{dE} / \mathrm{dt}|=1 \mathrm{mVs}^{-1}$.

where $V_{m}$ represents the molar volume of the bulk metal Cd, $F$ the Faraday constant, $D$ the diffusion coefficient of $\mathrm{Cd}^{2+}$ ions, $\mathrm{C} \mathrm{Cd}^{2+}$ the metal ion bulk concentration, and $\mathrm{t}_{0}$ the induction period. The nucleation rate $\mathrm{J}$ in equation (1) is defined by (Budesvski, et al., 1996)

$$
\mathrm{J}(\eta)=\operatorname{Aexp}\left[-\frac{\Delta G_{\text {crit }}(\eta)}{k T}\right]
$$

where $\Delta G_{\text {crit }}(\eta)$ is the Gibbs free energy for the formation of a critical cluster containing $\mathrm{N}_{\text {crit }}$ atoms. The pre-exponential factor $A$ includes the number of active nucleation sites as well as the attachment frequency of single atoms to nucleus. The nucleation rates $\mathrm{J}$ were derived from the slopes of these plots using equation (1) with $V_{m}=13,0074 \mathrm{~cm}^{3} \mathrm{~mol}^{-1}$ and $\mathrm{D}=$ $8,64.10^{-6} \mathrm{~cm}^{2} \mathrm{~s}^{-1}$ (Lobo, 1989). 


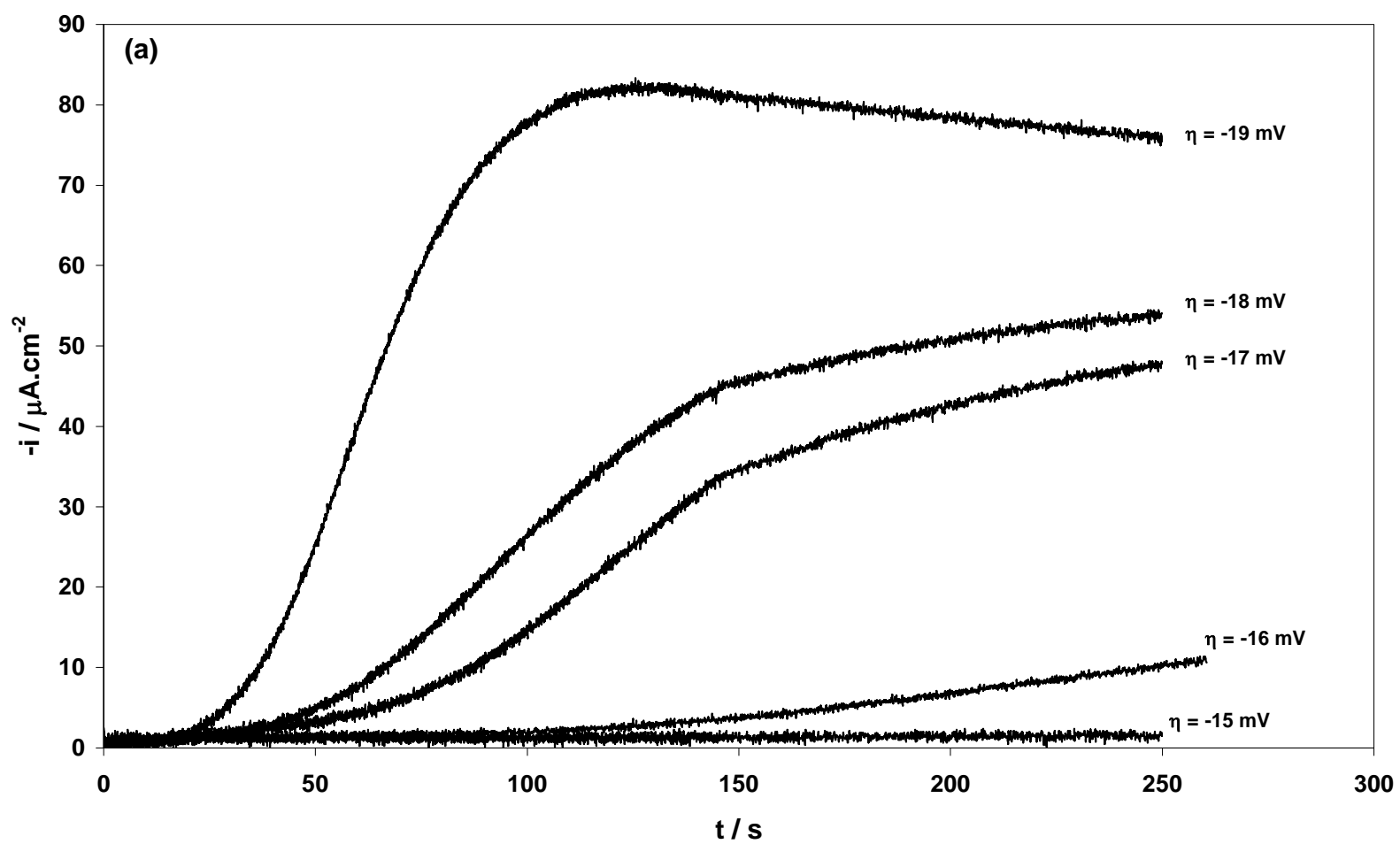

Figure 2a: Experimental current-time transients for Cd OPD at different overpotentials in the system n-Si(100): 20-40 ohm.cm / 5 $\times 10^{-3} \mathrm{M} \mathrm{CdSO}_{4}+0.5 \mathrm{M} \mathrm{Na}_{2} \mathrm{SO}_{4}+5 \times 10^{-3} \mathrm{M} \mathrm{H}_{2} \mathrm{SO}_{4} ; \mathrm{pH}=2.5, \mathrm{~T}=298 \mathrm{~K}$. Initial potential $\Delta \mathrm{E}_{\mathrm{i}}=\mathrm{E}-\mathrm{E} \mathrm{Cd} 2+, \mathrm{Cd}=0 \mathrm{mV}$.

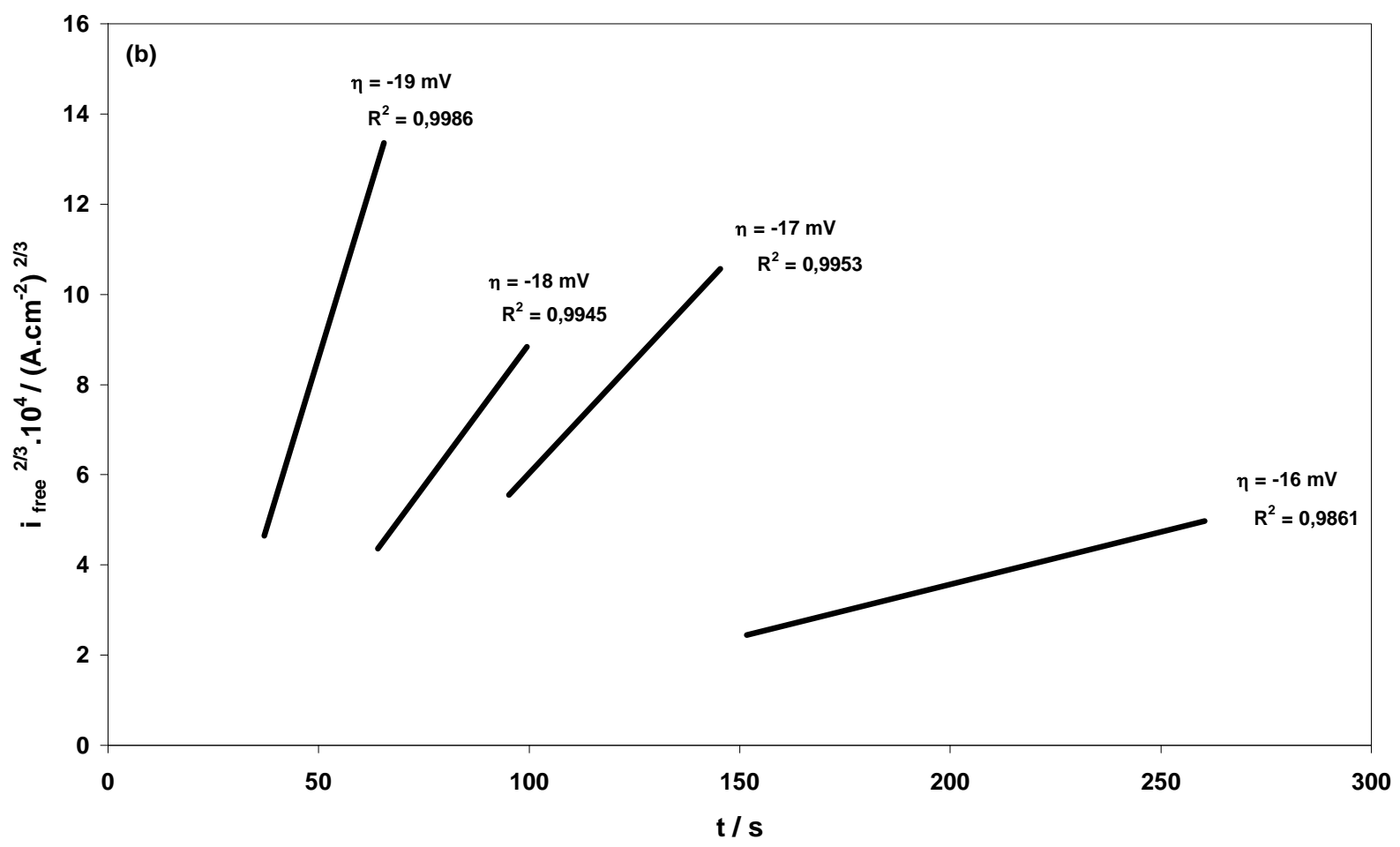

Figure $2 \mathrm{~b}: \mathrm{i}_{\text {free }}{ }^{2 / 3}$ vs. $\mathrm{t}$ plot of the initial parts of the transients shown in Figure $2 \mathrm{a}$.

Figure 3 shows the nucleation rate $\mathrm{J}$ as a function of the overpotential $|\eta|$ for the system under investigation. Linear In $\mathrm{J}-|\eta|$ dependence is obtained in this overpotential range with a coefficient of determination $\mathrm{R}^{2}$ greater than 0.9025 and in agreement with equation (2). The number of atoms $\mathrm{N}_{\text {crit }}$ in the critical cluster can be determined using equation (3)

$$
\mathrm{N}_{\text {crit }}=\frac{R T}{z F} \frac{d \ln J}{d|\eta|}
$$

In this equation the weak overpotential dependence of the preexponential, $A$, in equation (2) is neglected because it affects $\mathrm{N}_{\text {crit }}$ only by less than 1 atom. From the slope of the linear $\ln \mathrm{J}$ $|\eta|$ dependence shown in Figure 3 a value of $N_{\text {crit }}=16 \pm 1$ atoms was derived for the substrate in the overpotential range $-16 m V \geq \eta \geq-19 m V$ using equation (3). The small number of atoms in the critical cluster indicates that the nucleation process has to be described by the so-called atomistic model (Budesvski, et al., 1996). 


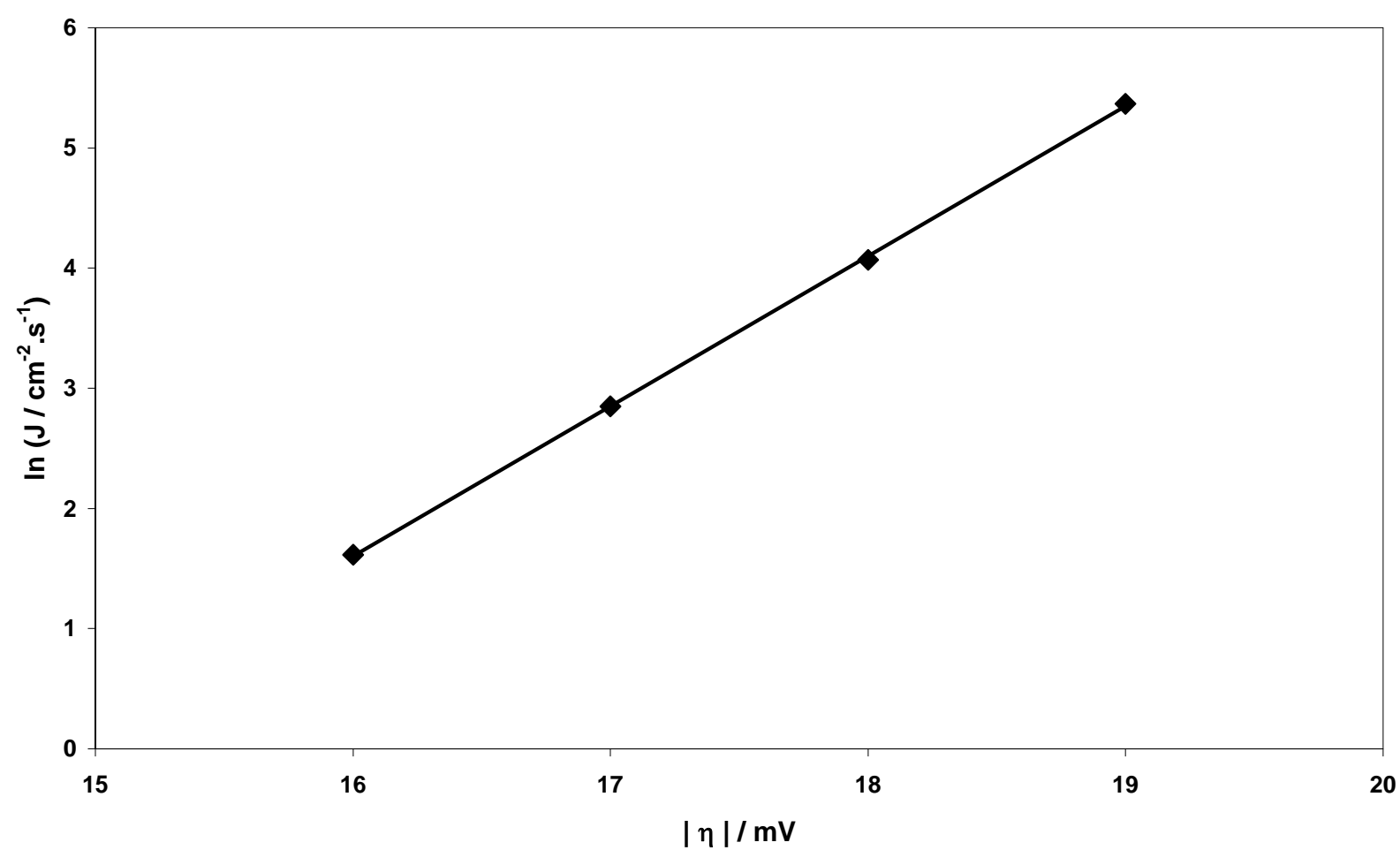

Figure 3: Nucleation rate $\mathrm{J}$ as a function of the overpotential . System n-Si(100): 20-40 ohm.cm / $5 \times 10^{-3} \mathrm{M} \mathrm{CdSO}_{4}+0.5 \mathrm{M}$ $\mathrm{Na}_{2} \mathrm{SO}_{4}+5 \times 10^{-3} \mathrm{M} \mathrm{H}_{2} \mathrm{SO}_{4} ; \mathrm{pH}=2.5, \mathrm{~T}=298 \mathrm{~K}$.

Coefficient of determination of the straight line: $R^{2}=0.9998 . N_{\text {crit }}=16 \pm 1$ atoms.

Deposition on $\mathrm{n}$-Si(111), phosphorus-doped, 40-60 $\Omega \mathrm{cm}$ resistivity.

Figure 4 shows a cyclic voltammogram of the system n-Si(111): $40-60 \Omega c m$ resistivityl $0.005 \mathrm{M} \mathrm{Cd}^{2+}$. The electrochemical behavior is the same as for $\mathrm{Cd}$ deposition on $\mathrm{n}-\mathrm{Si}(100)$ (described above) and on $\mathrm{n}-\mathrm{Si}(111)$ : $1-5 \Omega \mathrm{cm}$ resistivity, $0^{\circ}$ misorientation (Krumm, et al., 2000). The same analysis can also be applied in this case.
Typical current transients for nucleation and growth of $\mathrm{Cd}$ on n-Si(111): $40-60 \Omega \mathrm{cm}$ resistivity are shown in Figure $5 \mathrm{a}$. The obtained linear $\mathrm{i}_{\text {free }}{ }^{2 / 3}$ vs. $t$ relationships for the initial parts of the transients (Figure $5 \mathrm{~b}$, coefficient of determination $\mathrm{R}^{2}$ greater than 0.9025 ) correspond to a progressive nucleation and diffusion controlled cluster growth described by

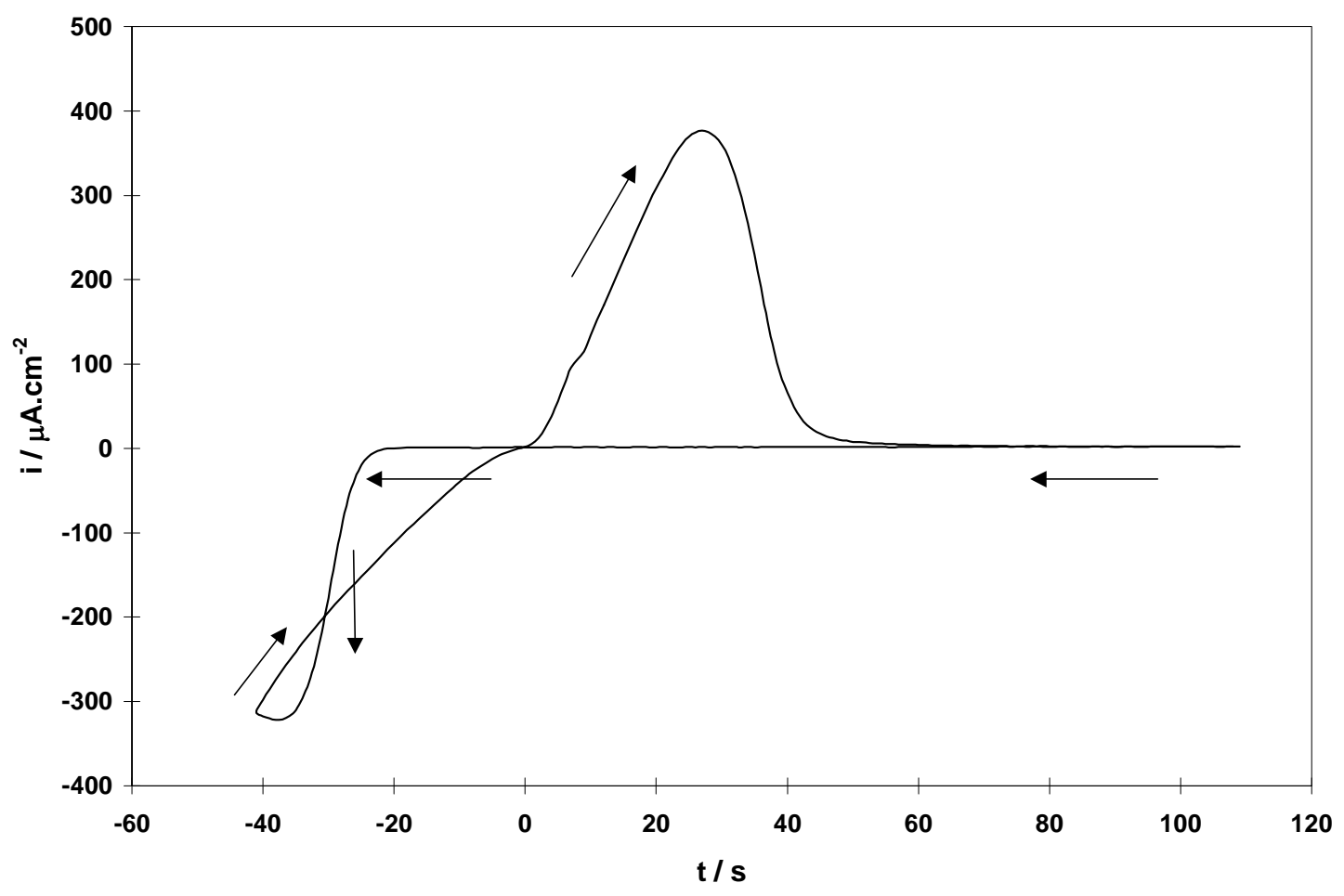

Figure 4: Cyclic voltammogram for Cd deposition and dissolution in the system n-Si(111): 40-60 ohm.cm / $5 \times 10^{-3} \mathrm{M} \mathrm{CdSO}_{4}+0.5$ $\mathrm{M} \mathrm{Na}_{2} \mathrm{SO}_{4}+5 \times 10^{-3} \mathrm{M} \mathrm{H}_{2} \mathrm{SO}_{4} ; \mathrm{pH}=2.5, \mathrm{~T}=298 \mathrm{~K},|\mathrm{dE} / \mathrm{dt}|=1 \mathrm{mVs}^{-1}$. 
equation (1). The nucleation rates $\mathrm{J}$ at different overpotentials were derived from the slopes of the $\mathrm{i}_{\text {free }}{ }^{2 / 3}$ vs. $t$ plots in Figure $5 b$ and equation (1). Applying equation (3), a value of $N_{\text {crit }}=7$ \pm 1 was estimated from experimental data denoting the linear In $\mathrm{J}-|\eta|$ dependence in the overpotential range $-14 \mathrm{mV} \geq \eta \geq$ $-18 \mathrm{mV}$ (Figure 6). Within experimental errors, these results are similar to those obtained for cadmium deposition on n$\mathrm{Si}(111)$ : $1-5 \Omega \mathrm{cm}$ resistivity, $0^{\circ}$ misorientation and indicate that: a) the miscut angle of (111) surfaces and the resistivity do not have a great influence on the value of $\mathrm{N}_{\text {crit }}$ in the critical cluster; b) the so-called atomistic approach has to be applied to describe the nucleation processes in these systems
(Budesvski, et al., 1996). Moreover, such a $\mathrm{N}_{\text {crit-value is not }}$ specific to $\mathrm{n}$-type (111) $\mathrm{Si}$ wafers. A $\mathrm{N}_{\text {crit-value ranging }}$ between 7 and 8 was found in the case of cadmium deposition on graphic HOPG (0001) substrate (Guel, 2007, University of

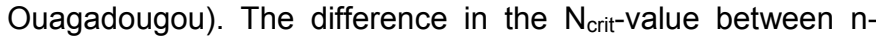
$\mathrm{Si}(100)$ and $\mathrm{n}-\mathrm{Si}(111)$ samples can be related to their different surface orientations. It was shown that when etching $\mathrm{Si}$ samples of different surface orientations (111) and (100), (100) faces show a larger concentration of kink sites that are more reactive (Allongue, et al., 1993). This could explain why the

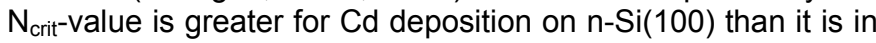
the case of $\mathrm{n}-\mathrm{Si}(111)$.

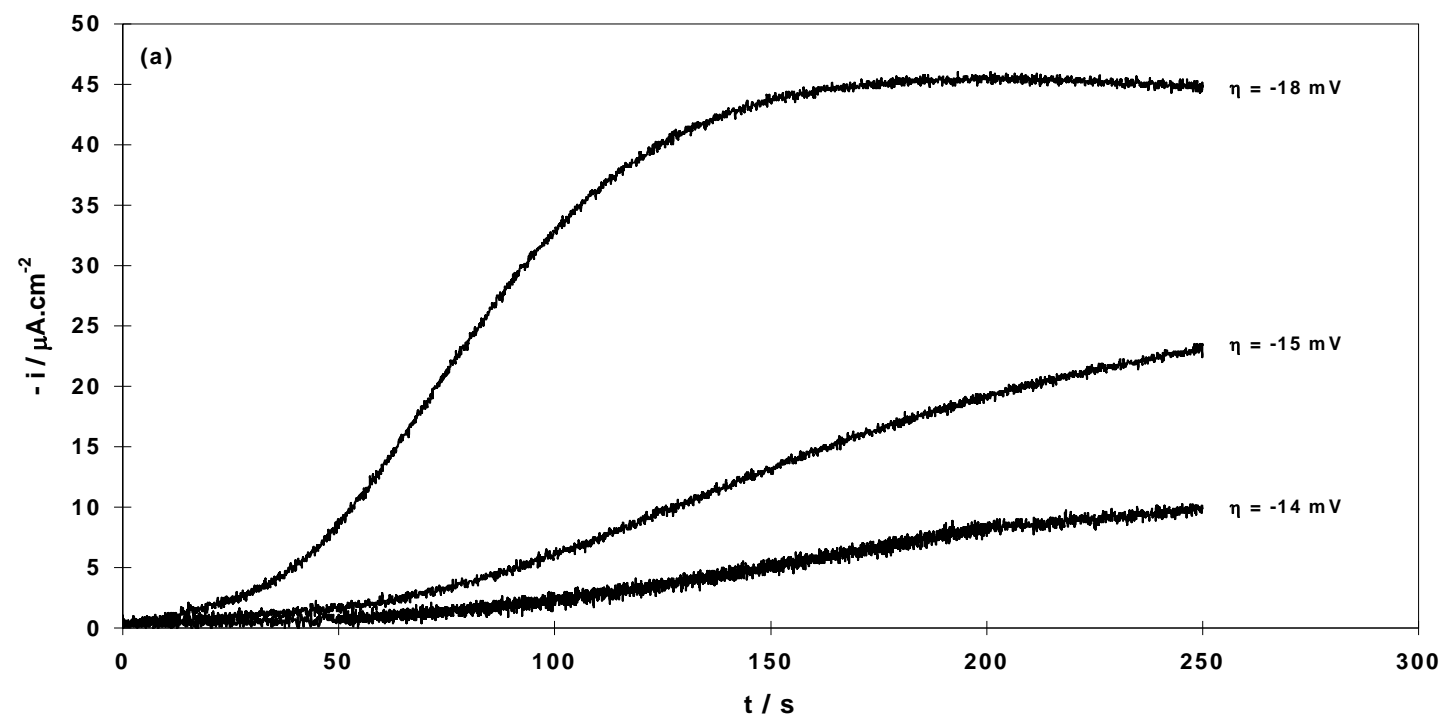

Figure 5a: Experimental current-time transients for Cd OPD at different overpotentials in the system n-Si(111): 40-60 ohm.cm / 5 $\times 10^{-3} \mathrm{M} \mathrm{CdSO}_{4}+0.5 \mathrm{M} \mathrm{Na}_{2} \mathrm{SO}_{4}+5 \times 10^{-3} \mathrm{M} \mathrm{H}_{2} \mathrm{SO}_{4} ; \mathrm{pH}=2.5, \mathrm{~T}=298 \mathrm{~K}$. Initial potential $\Delta \mathrm{E}_{\mathrm{i}}=\mathrm{E}-\mathrm{E} \mathrm{Cd} 2+/ \mathrm{Cd}=0 \mathrm{mV}$.

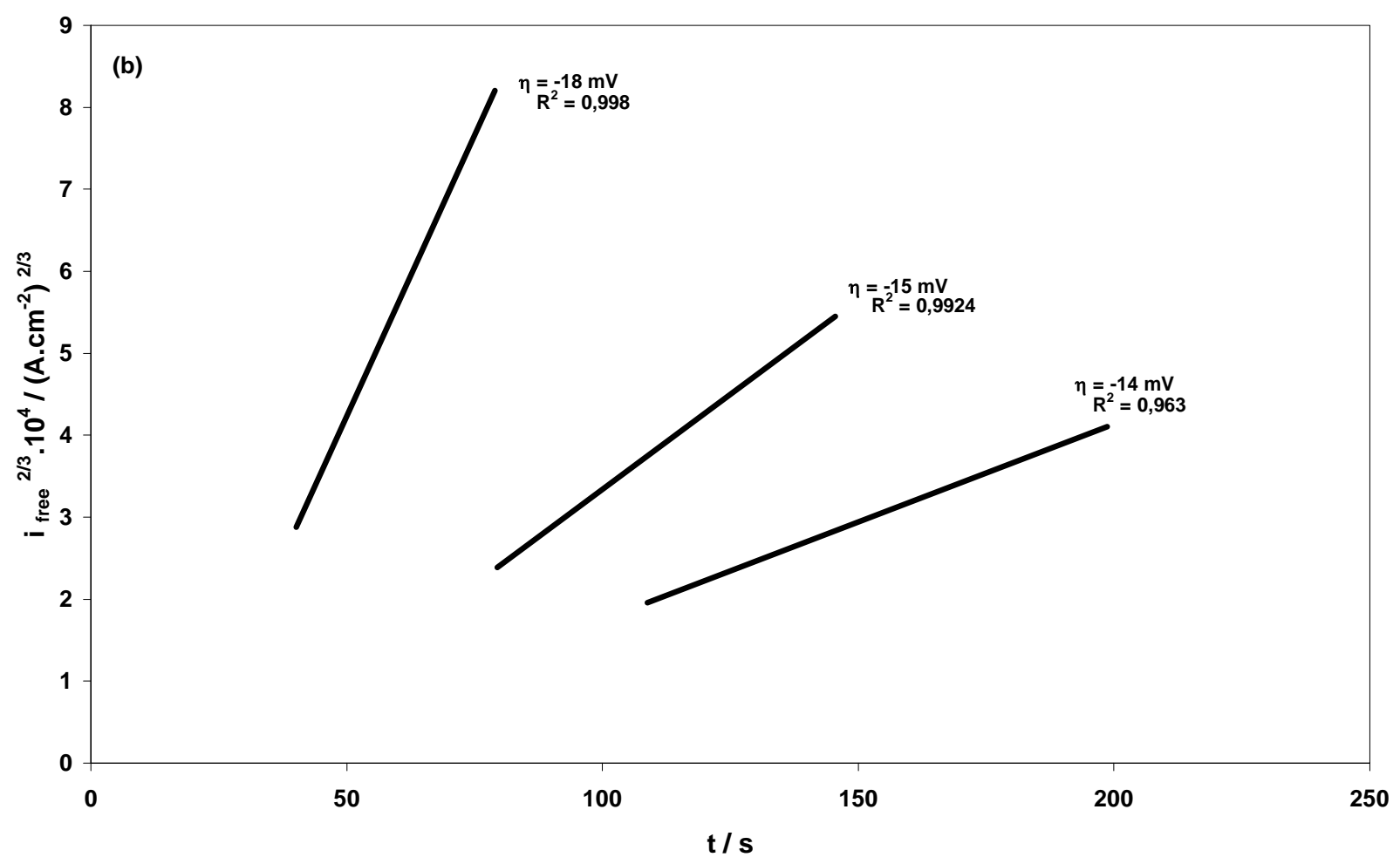

Figure $5 \mathrm{~b}: \mathrm{i}_{\text {free }}^{2 / 3}$ vs. $t$ plot of the initial parts of the transients shown in Figure $5 a$. 


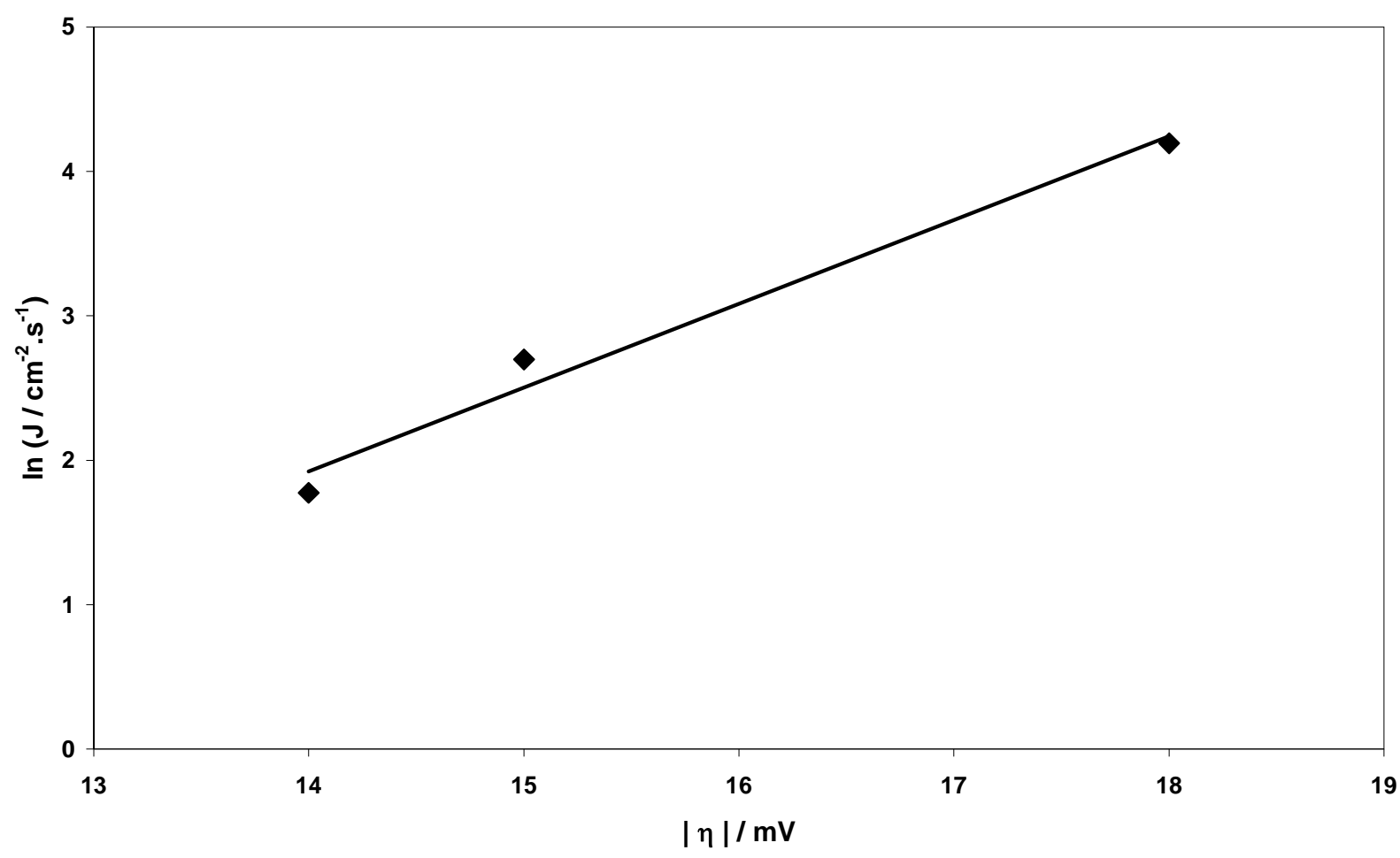

Figure 6: Nucleation rate $\mathrm{J}$ as a function of the overpotential . System n-Si(111): 40-60 ohm.cm / $5 \times 10^{-3} \mathrm{M} \mathrm{CdSO}_{4}+0.5 \mathrm{M}$ $\mathrm{Na}_{2} \mathrm{SO}_{4}+5 \times 10^{-3} \mathrm{M} \mathrm{H}_{2} \mathrm{SO}_{4} ; \mathrm{pH}=2.5, \mathrm{~T}=298 \mathrm{~K}$. Coefficient of determination of the straight line: $\mathrm{R}^{2}=0.9789 . \mathrm{N}_{\text {crit }}=7 \pm 1$ atoms.

\section{CONCLUSIONS}

The initial Cd deposition kinetics on $\mathrm{n}-\mathrm{Si}(100): 20-40$ $\Omega \mathrm{cm}$ resistivity and $\mathrm{n}-\mathrm{Si}(111): 40-60 \Omega \mathrm{cm}$ resistivity can be described by a model involving progressive nucleation on active sites and hemispherical diffusion towards the growing $3 \mathrm{D}$ Cd clusters. Within the investigated overpotential range the number of atoms in the critical cluster was found to be $\mathrm{N}_{\text {crit }}=$ $16 \pm 1$ and $\mathrm{N}_{\text {crit }}=7 \pm 1$ for $\mathrm{n}-\mathrm{Si}(100)$ and $\mathrm{n}-\mathrm{Si}(111)$ respectively. Such a difference in the $\mathrm{N}_{\text {crit-value can be related }}$ to the surface orientations of the silicon single crystals. The main factors determining the size of the critical nuclei and the Gibbs energy of nucleus formation are the supersaturation zF| $\eta \mid$ and the Cd-Cd interaction on top of an unmodified $\mathrm{Si}$ substrate. In all cases the low values of $\mathrm{N}_{\text {crit }}$ indicate that the thermodynamics and kinetics of electrochemical nucleation must be described by the so-called small cluster or atomistic model (Budesvski, et al., 1996).

\section{REFERENCES}

Allongue, P., 1992. Physics and Applications of semiconductor Electrodes Covered with Metal Clusters. In Conway, B. I., Bockris, J. O'M., White, R. E.(Editors) Modern Aspects of Electrochemistry Vol. 23. Plenum Press, New York, pp.239-315.

Allongue, P., Costa-Kieling, V., Gerischer, H., 1993. Electrochemical Studies of $n-S i(111)$ and (100) and Mechanism of the Dissolution. J. Electrochem. Soc. 140: 1018-1026.

Billo, E. Joseph, 1997. Excel for Chemists A Comprehensive Guide, WILEY-VCH, New York, 454 pages.

Bort, H., Jüttner, K., Lorenz, W. J., Staikov, G., 1983. Underpotential alloy formation in the system $\mathrm{Ag}(\mathrm{hkl}) / \mathrm{Cd}^{2+}$. J. Electrochim. Acta $28: 993-1001$.
Brillsoin, L. J., 1982. The Structure and Properties of MetalSemiconductor Interfaces. Surf. Sci. Report 2: 123326.

Budevski, E., Staikov, G. and Lorenz, W. J., 1996. Electrochemical Phase Formation and Growth- An Introduction to the Initial Stages of Metal Deposition, $\mathrm{VCH}$, Weinheim, 410 pages.

Djenizian, T., Petite, B., Santinacci, L., Schmuki, P., 2001. Electron-beam induced carbon deposition used as a mask for cadmium sulfide deposition on $\mathrm{Si}(100)$. Electrochim. Acta 47: 891-897.

Golan, Y., Margulis, L., Hodes, G., Rubinstein, I., Hutchison, J. L., 1994. Electrodeposited quantum dots II. High-resolution electron microscopy of epitaxial CdSe nanocrystals on $\{111\}$ gold. Surf. Sci. 311 : L633-L640.

Gómez, H., Henríquez, R., Schrebler, R., Riveros, G., Leinen, D., Ramos-Barrado, J.R., Dalchiele, E.A., 2004. A soft-solution electrochemical processing technique for preparing $\mathrm{CdTe} / \mathrm{n}-\mathrm{Si}(100)$ heterostructures. J. Electroanal. Chem. 574: 113-122.

Gómez, H., Henríquez, R., Schrebler, R., Córdova, R., Ramirez, D., Riveros, G., Dalchiele, E.A., 2005. Electrodeposition of CdTe thin films onto $\mathrm{n}-\mathrm{Si}(100)$ : nucleation and growth mechanisms. Electrochim. Acta 50 : 1299-1305.

Guel, B. 2007. Caractérisation structurale de diséléniures de métaux de transition et étude de quelques interfaces solide/électrolyte. Thesis, University of Ouagadougou, Burkina Faso, 252 pages.

Hodes, G., 1993. Size-Quantized Nanocristalline Semiconductors Films. Israel Journal of Chemistry 33: 95-106. 
Hodes, G., Howell, I. D. J., Peter, L. M., 1992. Nanocristalline Photoelectrochemical Cells A New Concept in Photovoltaic Cells. J. Electrochem. Soc. 139(11): 3136-3140.

Hümann, S., Hommrich, J. and Wandelt, K., 2003. Underpotential deposition of cadmium on $\mathrm{Cu}$ (111) and $\mathrm{Cu}(100)$. Thin Solid Films 428: 76-82.

Khader, M. M. and Saleh, M. M., 1999. Comparative study between the photoelectrochemical behaviors of metal-loaded n- and p-GaAs. Thin Solid Films 349: 165-170.

Krumm, R., Guel, B., Schmitz, C. and Staikov, G., 2000. Nucleation and Growth in Electrodeposition of Metals on $\mathrm{n}-\mathrm{Si}(111)$. Electrochim. Acta 45: 3255-3262.
Lobo, V. M. M., 1989. Handbook of Electrolyte Solutions Part A, Elsevier, Amsterdam, 300 pages.

Maupai, S., Zhang, Y. and Schmuki, P., 2003. Nanoscale obsevation of initial stages of Cd-electrodeposition on Au (111). Surface Science 527 : L165-L170.

Ortega, M., Santana, G., Morales-Acevedo, A., 2000. Optoelctronic properties of $\mathrm{CdO} / \mathrm{Si}$ photodetectors. Solid-State Electronics 44: 1765-1769.

Pötzschke, R. T., Staikov, G., Lorenz, W. J., Wiesbeck, W., 1999. Electrochemical Nanostructuring of $n-S i(111)$ Single Crystals Faces. J. Electrochem. Soc. 146 : 141-162.

Vidu, R. and Hara, S., 2000. Diffusion at $\mathrm{Au}(100) / \mathrm{Cd}^{2+}$ interface during electrodeposition. Surface Science 452 : $229-238$. 